\title{
Adult cell leukemia (ATL) in a patient with HTLV infection - case presentation
}

\author{
Gabriel Colțan ${ }^{1 *}$, Cristina Marin ${ }^{1}$, Mariana Anghel ${ }^{1}$, Tatiana Colțan ${ }^{1}$, Mihai Olariu', Ana Maria Vlădăreanu², \\ Elena Ambrus², Irina Pârvu' \\ From The 7th Romanian National HIV/AIDS Congress and The 2nd Central European HIV Forum \\ Sibiu, Romania. 29-31 May 2014
}

Infections with human retroviruses, others than the HIV virus, are not very well known in Romania, despite the fact that screenings for HTLV I and II are constantly performed in blood donation centers. The authors draw attention on the possible severe consequences that may occur in chronic infections with these viruses by presenting the case of a 35 year-old male, who was known to be infected with HTLV I virus for several years and who consequently developed adult cell leukemia.

The authors also plead for the development of an algorithm for the detection, surveillance, monitoring and treatment of HTLV infections, throughout interdisciplinary cooperation between infectious disease specialists, hematologists, dermatologists.

The authors strongly recommend the development of means to promote prevention by: securing blood transfusions; forbidding breastfeeding in women who tested positive for HTLV; using condoms in order to prevent sexual transmission in discordant couples.

\footnotetext{
Authors' details

'National Institute for Infectious Diseases "Prof. Dr. Matei Balş", Bucharest, Romania. ${ }^{2}$ University Emergency Hospital, Bucharest, Romania.
}

Published: 29 May 2014

doi:10.1186/1471-2334-14-S4-P50

Cite this article as: Colțan et al:: Adult cell leukemia (ATL) in a patient with HTLV infection - case presentation. BMC Infectious Diseases 201414 (Suppl 4):P50.

$\overline{1}$ National Institute for Infectious Diseases "Prof. Dr. Matei Balş", Bucharest, Romania

Full list of author information is available at the end of the article

Submit your next manuscript to BioMed Central and take full advantage of:

- Convenient online submission

- Thorough peer review

- No space constraints or color figure charges

- Immediate publication on acceptance

- Inclusion in PubMed, CAS, Scopus and Google Scholar

- Research which is freely available for redistribution

Submit your manuscript at www.biomedcentral.com/submit
C Biomed Central 